\title{
Night of the Living Bread: Unstable Signs In Chester's 'Antichrist'
}

\begin{abstract}
This essay contends that the title character of Chester's 'Antichrist' play disrupts orthodox models of language and theology through his biblical parody and mock resurrections. By destabilizing language and bodies through Antichrist's stage presence, the play speaks to a historical destabilization of sacred language and actions that arose during the play's earliest performance period because of the Lollard heresy. These disturbances in turn force theatrical and historical audiences to interpret religious signs through complex hermeneutical frameworks, frameworks I argue that the Chester 'Antichrist' play itself constructs.
\end{abstract}

The figure of Antichrist looms large in the late Middle Ages, making an appearance in every art form of the period, including drama. His notorious shape-shifting and flexible significations allow him to accommodate (and perhaps accumulate) a variety of heterodoxies; medieval texts depict him as part-devil, part-beast, and part-serpent; as tyrant, pope, and false prophet; and as a Jew and a Babylonian. Antichrist not surprisingly then becomes the poster child of unstable signs in Chester's 'Antichrist' play.

The late medieval tradition explicitly counterpoises Antichrist's words and deeds with Christ's (or another virtuous figure's) to delineate heterodox and orthodox faith. In the Chester 'Antichrist' play, this juxtaposition — between its titular antihero and its orthodox figures - is the source of Antichrist's destabilization of signs, both linguistically and materially. He consistently deploys parodic biblical language, exploiting the same register on which Christ draws elsewhere in the cycle and making his verbal heresy eerily resemble orthodox models. This parody forces the audience to depend on the context of Antichrist's words, rather than the words themselves, to interpret his meaning. Words, though, are not the only signs that Antichrist destabilizes. His deeds also invite scrutiny as he parades several possibly-resurrected bodies across the stage that necessitate a hermeneutic

Cameron Hunt McNabb (cameronhuntmcnabb@gmail.com) is an assistant professor in the department of English at Southeastern University. 
in order for the audience to interpret their heterodox or orthodox status. Along with the staging of Antichrist's biblical parody, the play's juxtaposition of true and false resurrections constructs specific — yet sometimes slippery — frameworks for interpreting words and deeds. Properly discerning Antichrist requires properly discerning his verbal and material signs.

How to distinguish orthodox from heterodox language and truly from falsely resurrected bodies were not just concerns surrounding Antichrist; they were central for medieval Eucharistic theology as well, as the host requires orthodox language to invoke the real presence of the truly resurrected body of Christ. Within the Chester 'Antichrist', the hermeneutic for determining orthodox words and deeds ultimately hinges on the miraculous power of the host. Rather than stage Antichrist against Christ, as the former's name suggests, the play pits Antichrist against the host. The real presence then embodies orthodox language and true resurrection while Antichrist (or perhaps Antihost?) signifies the opposite.

The play's attention to destabilized language and bodies through Antichrist's stage presence, and their recuperation through the host, speaks to a historical destabilization during the play's earliest performance period, arising from the threats of the Lollard heresy. The Lollards denied what Sarah Beckwith calls the supposed 'sacred immunisation' of the Latin scriptures and the host's real presence, and their resistance to such orthodox stability disrupted linguistic and material signs just as Antichrist does on stage. ${ }^{1}$ These disruptions in turn force theatrical and historical audiences to interpret such signs through complex hermeneutical frameworks, frameworks the Chester 'Antichrist' play itself constructs.

\section{'Nowe ys comyn thys daye'}

The Chester 'Antichrist' play depicts its title character's deconstructive efforts in a way that is embedded in the text's historical time and place, particularly in the heretical threat of Lollardy. Establishing the concurrent performance of the Chester 'Antichrist' and presence of Lollard heresy, however, requires strategic sifting through a wealth of extant materials. Eight manuscripts survive that contain some or all of what modern scholars call the Chester cycle, which is itself a constructed myth of preferred texts and editorial choices. The manuscript tradition offers five complete versions of the cycle, four fairly similar manuscripts (called the Group) and a fifth quite distinct. ${ }^{2}$ All five manuscripts contain 'Antichrist', but they all date to the post-Reformation sixteenth century, far past Lollardy's heretical heyday in England. The earliest version of the text, however, can be found in the Peniarth manuscript dating to 'the end of fifteenth-century', a window squarely 
within Lollardy's period of influence. ${ }^{3}$ Surviving secondary documentation further complicates the record by suggesting significant differences from the extant manuscript tradition concerning the number, order, and content of plays performed. R.M. Lumiansky and David Mills astutely propose that the extant primary and secondary texts represent evidence both of an evolving cycle and residue of the exemplar system, in which plays were variously copied out, revised, moved, and even provided with alternative readings. ${ }^{4}$ The 'Chester cycle' thus consisted less of a fixed corpus of plays than, in Lumiansky and Mills's apt phrase, a 'cycle of cycles.' ${ }^{5}$ The cycle itself, then, is an unstable sign. ${ }^{6}$

Mills notes that Chester originally performed its plays, in whatever form, as part of Corpus Christi day, when the church celebrated the real presence and 'affirmed the authority of the Church rooted in the priestly power to effect transubstantiation.7 The first documented historical reference to a Corpus Christi play in Chester dates to 1422, but the reference does not delineate what pageants were played. ${ }^{8}$ Lumiansky and Mills locate the earliest reference to the 'Antichrist' play specifically in $1467-8$, and the Peniarth manuscript follows by the end of the century. These documents collectively suggest an estimated date range for the play's early performance history in the 'cycle of cycles'.

The Chester cycle is unique among medieval English drama in its inclusion of an Antichrist play. Technically, the cycle contains two: first, the prefatory play 'Antichrist's Prophets', which is a catalogue of biblical characters expounding prophecies regarding Antichrist, and, second, the 'Antichrist' play itself, which enacts the antihero's deceptions until the archangel Michael defeats him. The two plays are situated between 'Pentecost' and 'The Judgment', indicating their protagonist's position in chronological limbo; Antichrist, like the Last Judgment, can come anytime. These flexible bearings allow for both contemporary allusions and historically based readings as the play attempts to ground its significations in the ever-shifting present. As the archangel Michael emphasizes to Antichrist, 'nowe ys comyn thys day' (625, emphasis mine). ${ }^{10}$ In fact, the word 'nowe' appears fifty-one times within the text.

Despite the play's temporal immediacy, only two scholars posit connections between it and possible historical referents (the heretical Antichrists of 'nowe'), and both overlook the most prevalent heretics during the play's earliest performance history (and the only heretics actually named in the text), the Lollards. Karen Sawyer Marsalek, in an essay on 'false resurrections' in Chester's 'Antichrist' and Shakespeare's 1 Henry IV, compellingly connects Antichrist's and Falstaff's faux resurrections, but she reads the Chester play in a mid-sixteenth-century context, suggesting that Antichrist's accusation against Enoch and Elijah as Lollards is 
an earnest concession to a Reformation audience. At the same time, she admits that 'such an incorporation of reformist ideas would unfortunately be undercut by Elias's use of a miraculous host to destroy Antichrist's illusions. ${ }^{11}$ She does not resolve this interpretive tension, nor does she hypothesize any pre-Reformation models of audience reception. Richard Emmerson more extensively analyzes possible audience receptions, arguing that the play's 'reception was heavily implicated by political and religious developments' and providing possible audience receptions based on three distinct historical periods during which it was performed: the early sixteenth century, pre-Reformation; the Henrician period of Reformation in the mid-sixteenth century; and the early Elizabethan settlement of the late sixteenth century. ${ }^{12}$ He notes that the identification of Antichrist would be heterogeneous within each period and would also shift across each era, resisting any singular signification or unified audience response, but he does not address the role the spread of Lollardy would have had on the pre-Reformation interpretation of Antichrist because he speculates that 'Lollardy ... had very little influence in northwest England throughout the fifteenth century.' ${ }^{13}$ While Emmerson draws this conclusion based on John A.F. Thomson's and Christopher Haigh's extensive work on the heresy, Anne Hudson challenges this assumption by citing Arundel's 1407 accusation of William Thorpe as working for twenty years 'in pe norp lond' as well as cases of Lollardy as far north as York and even in Scotland. ${ }^{14}$ Hudson contends that while 'material for the north is the most exiguous', 'texts in a limited way support these hints that Lollardy was not unfamiliar in the north'. ${ }^{15}$ The reference to Lollards in the Chester 'Antichrist' supports these hints as well. We can further contextualize audiences' receptions of Antichrist's unstable linguistic and material signs only by analyzing the text's early connection with Lollardy, a connection Emmerson and Marsalek both overlook.

The Chester 'Antichrist' responds to the historical presence of Lollardy through its foregrounding of heresy and through its deeply orthodox arguments against Lollard theological tenets. The text's initially unstable deployment of the word 'heresy' subverts audience expectations. Antichrist employs it the first two times ironically in an attempt to convert the four kings to his own Antichristian faith. He first says to them, 'I putt you oute of hereysye / to leede me apon' (87-8), and later declares to rival evangelists Enoch and Elijah, 'But I shall teche you curtesye, / youre savyor to knowe anon in hye, / fals theffez with youre herysye' (377-9). The doctor, a counselor to Antichrist, echoes this characterization by referring to the two prophets as 'yendre herytykes' (439). Antichrist's initial coding thus attempts to cast Enoch and Elijah as heterodox and himself as orthodox, a move that co-opts the term heresy in order to shore up the rhetorical power of 
his own theological argument and slyly suggests that heresy may be in the eye of the beholder. The text also addresses the Lollard heresy specifically, as Antichrist remarks of Enoch and Elijah

These lowlers, they wolde full fayne me greve

and nothing on me will they leve,

but ever ben redye me to repreve

and all the people of my lawe.

Lumiansky and Mills gloss 'lowlers' as Lollards and note that the word 'picks up the emphasis on heresy seen elsewhere in the play.' ${ }^{16}$, The term 'heresy' turns, however, at the precise moment the four kings reject Antichrist and are converted to the orthodoxy of Enoch and Elijah by the power of the host. When the third king repents, he exclaims, 'And nowe knowyn apertely / we have ben broghte in herysye' (589-90), and the first king confirms that Antichrist 'hasse us led in heresye' (599). The four kings' proper recognition of the host reverses the coding, confirming Antichrist as the heretic indeed.

As Bernard McGinn notes, 'Antichrist was often seen as a heretic, and a leader of heretics. ${ }^{17}$ But the play offers clear theological indications of Antichrist's specific heresy - a denial of the real presence, and, most importantly, an implicit accusation that he is a 'lowler' (428). ${ }^{18}$ Lollardy's unorthodox reading of the church's most venerated sign challenged the assumed univocity with which it signified. ${ }^{19}$ The Chester play reasserts this univocity as the real presence of the host overcomes the four kings' theological errors and initiates their conversions. The consecration scene, which acts as a theological tie-breaker between Enoch and Elijah and Antichrist, thus demarcates the orthodox-heterodox line quite clearly. (Notably, Antichrist's theological dissent, not his name, identifies his heretical nature, for his heterodox views emerge midway through the play, but he remains unnamed until Michael calls him 'Antecist' in line 625). ${ }^{20}$ Antichrist's battle is against Christ in the host, an encounter in keeping with the cycle's Corpus Christi origins and appropriate to its early audience, who themselves can defeat Antichrist (and Lollardy) by believing in the real presence. Emmerson notes that the raising of the host does not appear in other Antichrist narratives, remarking that 'the scene, probably added to underscore the cycle's celebration of Corpus Christi, reinforces the orthodox nature of Chester's Antichrist'. ${ }^{21}$ Not only does this action underscore the orthodoxy of the play's righteous figures, but it also highlights the heretical, and in this case Lollard, nature of Antichrist as he negotiates the period's most contested sign, the host. ${ }^{22}$ 
Antichrist's verbal and material disruptions reflect Lollardy's two primary concerns - resisting the inherent stability of Latin as the language of scripture and denying the truly resurrected body of Christ in the host. As the play asks late medieval audience members to discern his heterodoxy, it forces them to rely on complex hermeneutics to interpret Antichrist's highly unstable words and deeds, a practice that the play encourages them to repeat outside the theatrical space, particularly in discerning contentious theological matters such as the real presence of the host.

\section{'Are not my wordes at your assent?': Discerning Language}

Scholarship on biblical plays has long discussed characterization through language; however, this research has overwhelmingly been focused on villain and tyrant figures' use of bombastic alliterative lines. ${ }^{23}$ Yet less generic, more parodic antagonists also take the stage, particularly Chester's Antichrist, and little work has been done on how their language signifies. ${ }^{24}$ How does Antichrist's biblical parody disrupt orthodox models of absolute or univocal language and the privileged position of Latin as the language of truth?

Chester's Antichrist, like most Antichrists, is an inverted Christ figure, with his biblical parody as his most obvious inversion. Biographically, Antichrist presents what Emmerson calls a 'sham imitatio Christi': ${ }^{25}$ he promises that he will die (121), be laid in a tomb $(125-6,136-7)$, be raised again $(123,129)$, and then send his spirit out to his people (131). He was, moreover, begotten in 'clene horedom' (672). His parody of scriptural passages develops this inversion of orthodoxy more fully, and the Chester play characterizes this disruption as an inverted tree. As Antichrist proclaims in his opening speech,

Now wyll I turne, all thrughe my myght,

Trees downe, the rote upright -

That ys marvell to youre sighte -

And frute groing upon.

This image of uprooting a tree so that the roots grow the fruit provides a metaphor for the parodic type of biblical interpretation in which Antichrist engages - he turns the passages upside down and then forces them to bear false significations. ${ }^{26}$ Satan in the desert likewise tempts Christ by invoking biblical passages to encourage Christ to break his fast, test the angels' protection of him, and rule over earthly kingdoms. In each temptation, Christ replies with other biblical passages, appropriately contextualized, defeating Satan's blasphemous application of 
the word with a more faithful reading. ${ }^{27}$ Only the branches of scripture must bear fruit, not the roots.

The play asks how one can know the difference between the two. Like Satan in the desert, Antichrist quotes biblical passages to support his own claims to divinity, but this is a practice Christ uses often as well. The word of God and the word of the tempter (Satan or Antichrist) are one and the same; only the context, inverted or upright, determines meaning. ${ }^{28}$ The biblical text in and of itself is not exempt from abuse, and in an inappropriate context - like in support of Antichrist's claims to divinity - it can signify vice rather than virtue. Such misappropriation is the nature of Antichrist's biblical parody in the play. The simple employment of biblical language thus cannot sufficiently demarcate orthodoxy or heterodoxy; discernment of moral meaning requires a more complex hermeneutic.

Paramount in the discussion of Antichrist's parody is language choice. Antichrist's quotations of Latin scripture simultaneously rely on and subvert Latin's assumed authority, forcing meaning to derive not simply from the use of Latin itself, a practice most associated with virtuous characters in the cycle, but from context. This subversion is most evident in Antichrist's opening Latin lines, which his lack of actions (he has yet to perform any) leave uncontextualized and thus more closely resemble God's or Christ's Latin introductions in preceding plays. ${ }^{29}$ Without corroborating evidence of the speaker's morality, Antichrist's opening Latin passages initially signify the virtue and authority attached to the language. Emmerson finds this 'dramatic control of the spiritual and authoritative language genuinely frightening. ${ }^{30}$ One might even say Satanic: Antichrist's passage here parallels Satan's Latin biblical quotations in desert. Only the context of the quotations, not the language itself, demarcates evil.

Antichrist opens the play by announcing his presence in Latin, which forges an immediate parallel between him and previous characters who begin a play with a Latin self-identification: God introduces 'Lucifer', 'Adam and Cain', and 'The Judgement' with 'Ego sum alpha et omega' while Jesus begins with, 'Ego sum lux mundi. Qui sequitur me non ambulat in tenebris sed habebit lumen vitae' (1 sd) in 'The Blind Man and Lazarus' and 'Pax vobis; ego sum; nolite timere' (1 sd) in 'Ascension'. The prophet Ezechiel also opens the play immediately prior to 'Antichrist', 'Antichrist's Prophets', with Latin: 'Facta est super me manus domini et eduxit me spiritus domini, et demisit me in medio campi qui erat plenus ossibus, et [circumduxit] me per ea in giro' (1 sd). However, the longest Latin introduction in the entire cycle (three times the length of God's ${ }^{31}$ ) belongs to Antichrist: 
De celso trono poli, pollens clarior sole, age vobis monstrare descendi, vos judicare, Reges et principes sunt subditi sub me viventes.

Sites sapientes vos, semper in me credentes et faciam flentes gaudere atque dolentes.

Sic omnes gentes gaudebunt in me sperantes.

Descendi presens rex pius et perlustrator, princeps eternus vocor, Cristus, vester salvator.

A declaration of divinity in English quickly corroborates the virtuous and authoritative associations that these Latin verses invoke: 'Youre savyor nowe in youre sight / here may you savely see. / Messyas, Criste, and most of might' (11-13).

To further the parallels between himself and the cycle's divine figures, Antichrist cites four biblical passages as evidence supporting his claims to divinity. ${ }^{33}$ He boldly announces that 'I shall fulfill Holly Wrytt' (113) just as Christ claims he came to fulfill the law, ${ }^{34}$ and as evidence he exclaims, 'De me enim dicitur Ezechiel tricesimo sexto: "Tollam vos de gentibus et congregabo vos de universis terris, et reducam vos in terram vestram" (24 sd). ${ }^{35}$ Here Antichrist parodies the traditional, biblical referents of people and land: he will take people from 'among the heathen' into their own land, but those people are the damned and their land is hell. Antichrist inverts the context of the quotation to redirect its meaning. His justifications continue two stanzas later with 'De me enim dicitur in psalmo: "Adorabo ad templum sanctum tuum in timore tuo" (40 sd). 36 The context of this passage within the whole Psalm highlights its irony. The verses immediately before it assure that ' $[n]$ either shall the wicked dwell near thee: nor shall the unjust abide before thy eyes. Thou hatest all the workers of iniquity: Thou wilt destroy all that speak a lie. The bloody and the deceitful man the Lord will abhor' ${ }^{37}$ Antichrist's declaration that worshippers will come into his temple also foreshadows his inverted ascension to the throne later in the play (624 sd), with the imperatives in the next Psalm verse to 'conduct me' and 'direct my way' being particularly ironic. ${ }^{38}$

Antichrist continues his parodic campaign as Christ with two other biblical supports: 'Daniellis terciodecimo: "Dabit eis potestatem. Mult[is] terram dividet gratuita" (56 sd) ${ }^{39}$ and 'Sophonie tercio: "Expecta me in die resureccionis mee in futurum quia judicium ut congregem gentes et colligam regna" (120 sd). ${ }^{40}$ The ambiguous subject of the Daniel passage — the 'he' who will cause them to rule over many — becomes clear when the verse is read in context: 
And the king shall do according to his will, and he shall be lifted up, and shall magnify himself against every god: and he shall speak great things against the God of gods, and shall prosper, till the wrath be accomplished. For the determination is made. And he shall make no account of the God of his fathers: and he shall follow the lust of women, and he shall not regard any gods: for he shall rise up against all things. But he shall worship the god Maozim in his place: and a god whom his fathers knew not, he shall worship with gold, and silver, and precious stones, and things of great price. And he shall do this to fortify Maozim with a strange god, whom he hath acknowledged, and he shall increase glory and shall give them power over many, and shall divide the land gratis. ${ }^{41}$

The glory, power, and land are signs not of a righteous ruler, as Antichrist attempts to make the passage show, but rather of an idolatrous king who 'shall rise up against all things'. The partial quotation from Zephaniah functions similarly, given the context of the verse. Antichrist employs the passage to gather the four kings around him to witness his resurrection, but the assembling that the passage refers to precedes God's intent to 'pour upon them my indignation, all my fierce anger: for with the fire of my jealousy shall all the earth be devoured', the second half of the verse that Antichrist conveniently omits. ${ }^{42}$

Lastly, like Christ Antichrist mentions references to himself 'in prophecye / off Moyses, Davyd, and Ysaye. / I am he they call messye, / forbyer of Israell' (17-20). Mills suggests specific passages from Deuteronomy, Psalms, and Isaiah that mention the messiah, but he also observes that 'all ... also contain warnings against false prophets, lending irony to the allusions'. ${ }^{43}$ Antichrist finally bequeaths his spirit to the kings, pronouncing in Latin, 'Dabo vobis cor novum et spritum novum in medio vestri' (196 sd). ${ }^{44}$ Again, the parody is clear: the new heart and new spirit are ones of damnation, not salvation.

But if Antichrist wields Latin as a guarantee of truth, two can play that game. Like Christ in the desert, the righteous figures of the play fight back with properly contextualized Latin. 'Antichrist' does provide two instances of orthodox uses of Latin, although both are liturgical rather than biblical passages, reinforcing ecclesiastical power. First when Elijah consecrates the host, he blesses it, 'In nomine Patris ... et Filii virginis ... et Spyrytus Sancti' $(573,574,575)$. This first use of authorized Latin notably comes immediately after Antichrist's last use of Latin parody, marking a shift in the Latin register of the play. After the consecration of the host and subsequent conversion of Antichrist's former followers, Antichrist ceases his parodic employment of the language, leaving its use to the orthodox figures. Secondly, at the play's conclusion, when the Angel leads Michael and the 
resurrected Enoch and Elijah offstage, the stage directions indicate that he sings the liturgical 'Gaudete justi in domino' (726 sd). ${ }^{45}$

All of the play's Latin uses collectively create the hermeneutical framework the audience needs in order to discern orthodox from heterodox linguistic signs: virtuous language, such as biblical quotations and liturgy, must be coupled with appropriate linguistic or material contexts, such as orthodox practice, in order to signify a righteous meaning. Such a hermeneutic directly responds to Antichrist's (and by extension, the Lollards') attack on the sanctity and inerrancy of Latin by arguing that not only the written text but also its ecclesiastical context are necessary for proper interpretations. Otherwise, as a contemporaneous antiLollard poem mocks, 'Per pe bibell is al myswent / to iangle of Iob or Ieremye, / Pat construen hit after her entent / For lewde lust of Lollardie'. ${ }^{46}$ Construing after one's own intent is the precise danger that the play's hermeneutical framework seeks to avoid.

But this framework also raises a number of questions concerning audience. Those fluent in Latin would have been more attuned to Antichrist's subtle mishandling of the biblical passages, and they likely would have discerned Antichrist's speciousness earlier than those who did not know the language. Antichrist explicitly acknowledges this audience demographic when he prefaces one of his Latin quotations with 'I shall reherse here redylye / that clerkys shall understond' (119-20). But how does a lay audience recognize 'virtuous language' or 'appropriate context' if it does not know the Latin scriptures well enough to discern either? If the sanctioned Latin of the church, such as the liturgy staged in the play, is one guarantor of orthodox meaning, how are these accessible to the laity? As Janette Dillon cautions, 'It is perhaps more helpful to think of plays as having access to a plurality of languages and then to explore how particular plays manipulate the boundary between different languages within what we know of their potential audiences. ${ }^{47}$ Through this plurality of languages, the play provides multiple moments of discernment regarding Antichrist's deception, and these moments depend on the audience's linguistic knowledge. For the laity, who were not fluent in Latin, Antichrist's opening lines and expository use of Latin passages evoked contradictory interpretations - at first, the audience would assume such quotations signified authority but then, after Antichrist's heterodoxy is revealed, would recognize the inversion of that authority. Antichrist's parody would have initially fooled the audience, as it did the kings and resurrected men within the play, a 'genuinely frightening' prospect, to borrow Emmerson's phrase.

Importantly though, the play couples moments of orthodox Latin with moments of orthodox practice, particularly involving resurrected bodies: the 
Latin consecration of the host leads to the real presence of the resurrected Christ, while the liturgical song at the play's conclusion accompanies Enoch, Elijah, and Michael's ascensions back into heaven, sharply contrasted with Antichrist's prior descent into hell. The laity's impetus of discernment here shifts from the linguistic signs introduced by Antichrist at the play's opening to the physical sign of the host at the play's climax and denouement. What was predominantly verbal for the 'clerkys' becomes predominantly material for the laity, and the play deftly negotiates both modes of meaning-making.

\section{'Take his bodye yt ys my reade': Discerning Bodies}

If the Chester 'Antichrist' play's linguistic signs are unstable, its physical signs are little better at grounding signification. Just as the play asks audience members to distinguish between orthodox and heterodox language, it demands they discern between orthodox and heterodox resurrections as well, and the most important resurrection they need to consider is the real presence of the host. Chester's 'Antichrist' dramatically confirms the real presence by making the Eucharist the vehicle for determining true and false resurrections. The host's saving power ultimately defines orthodoxy, while Antichrist's illusionary magic show becomes elided with the false appearances of Lollardy - things are not as they seem. A resurrection is not always a resurrection, and, more importantly, bread is not always bread.

To differentiate between these appearances and reality, the Chester 'Antichrist' play requires its audience, once again, to base interpretations on appropriate contexts. The play constructs this hermeneutic through a contest of resurrections between Antichrist and Enoch and Elijah, spurred on by the two sides' opposing theological claims. The bulk of the play encompasses a rather tedious flyting match between Antichrist and the prophets, who hurl insults, rebukes, and curses at one another for 220 lines. Their core debate centres on the authenticity of their own claims about divinity - Antichrist's insistence that he is Christ, and Enoch and Elijah's denial of this assertion. This claim necessitates evidence, in the form of resurrected bodies, and Antichrist promises to deliver such proof:

That I am Crist and Crist wilbe by verey signes sone shall ye see, for dede men thrughe my poste shall ryse from dethe to lyve. 
He expands the terms a few lines later to include self-resurrection:

Forsothe, then after will I dee

and ryse agayn thrughe my poostye.

Yff I may do thus marvlosly,

I redd you on me leve.

Enoch and Elijah deny the validity of Antichrist's claim to divinity and, to prove their case, they agree to the contest:

Wythe this champion we most chyde,

That nowe in worlde walkys wyde,

To disspreve his pompe and pryde

And payre all his poostye.

Marsalek notes a verbal parallel between Christ's raising of Lazarus in 'The Blind Man and Lazarus' and Antichrist's boast: Mary refers to Lazarus's resurrection as evidence of Christ's divinity, 'By verey signe nowe men maye see / that thou arte Godes Sonne' (476-7). The contest between true and false resurrections necessitates interpretation of these 'verey signes'.

The dramatic judges of this contest are the four kings who will believe in whoever practices true resurrection, and they explicitly call for 'a signe' (68) to determine the winner. The audience too must judge such signs, and, as the four kings explain, their belief is at stake. To Antichrist, they declare, if 'thow goo; / so that thow save us of oure woo, / then honoryd shall thowe be' (70-2), and later to Enoch and Elijah, they state, 'if youre skyllys may do hym [Antichrist] downe, / to dye withe you we wilbe bowne / in hope of sawlw salvacon' (321-3). All parties seem to agree to the terms of the contest, accepting that what determines Antichrist's authentic or specious divinity will be his ability to raise people from the dead.

This contest plays out in two rounds, first exploring earthly resurrections and then eternal ones. The competition of earthly resurrections begins when Antichrist exclaims, 'Ryse up, ye dede men, and honures me / and knoys me for youre lorde' (103-4). Two dead men rise up, according to the speech prefixes (Primus Mortuus and Secundus Mortuus respectively), and Primus Mortuus attempts to validate his resurrection by stating, 'I wos dede but nowe lyve I' (106). This line initially might seem like an obvious definition of resurrection, but the 'I wos dede' portion becomes crucial in terms of resurrection taxonomy. A similar statement is made regarding Lazarus earlier in the cycle. Jesus first says metaphorically that Lazarus sleeps, but when John takes this literally, Jesus emphasizes that 
Lazarus is not sleeping but is 'certenly' dead (365-6). The dead men in Chester's 'Antichrist' likewise insist that they were not merely sleeping or comatose. They were really dead and are now undead. This simple quality of a true resurrection, though, creates a problem for Enoch and Elijah, who first appear on stage having never died. They seem to be nondead but not undead. If one has not been dead, can one truly be resurrected?

Antichrist tries to bolster his claim to divinity by dying and resurrecting himself, exclaiming theatrically, 'I dye! I dye! Nowe am I dede' (133). This scene includes numerous parallels to Christ's death, with Antichrist promising to send his spirit and being laid in a tomb. Then the stage directions indicate, 'Tunc Antechristus levat caput suum surgens a mortuis' (164 sd), ${ }^{48}$ and he proclaims,

I rise! Nowe reverence dose to me,

God glorifyd, grattist in degre.

Iff I be Criste, nowe levys ye

and warchis after the wyse.

Antichrist too emphasizes his undead status as evidence of his resurrection and thus of his divinity.

Enoch's and Elijah's own miraculous presences onstage attempt to combat Antichrist's resurrections; however, their status as nondead but not undead complicates the kings' and audience's interpretation of their presences. Enoch says he has lived eternally in paradise 'sythe the worldis begynyng' (269). The kings confirm, 'We redon in bokys of oure lawe / that they to hevon were idrawe' (3056). The two prophets make clear that God 'so long in fleshe and blude / hasse grauntyd lyve and hevonly fode' (263-4), and Michael clarifies that 'ye have ben long, for ye ben wyse, / dwellyng in erthlye paradyce' (719-20). These descriptions indicate that Enoch and Elijah never died but remained in earthly bodies while in an earthly paradise. (Michael contrasts this place with heaven, which is where they will go at the end of the play). Enoch and Elijah's contention that their own real presences, despite their slippery ontological status, can compete with Antichrist's three supposedly resurrected bodies (the two dead men plus himself) initially appears dubious.

If the audience is to believe the 'verey signes', their sympathies are not firmly placed at this midway point in the play. The contest has featured three fairly convincing bodies resurrected by Antichrist, all of whom have, like Lazarus, 'passed from death to life, ${ }^{49}$ versus two suspicious resurrections of the never-dead Enoch and Elijah. Like the Latin scriptures presented earlier in the play, the 'verey signes' 
of bodily resurrection do not signify clearly. The audience requires something more in order to discern orthodoxy from heterodoxy.

That something more is the host. The final match between the two sides occurs when Elijah proposes to test Antichrist's resurrections:

Yff tho men be raysyd witterlye

withouten the devuls fantasye,

here shall be prevyd appertely

that all men shall see.

Enoch follows up with the specifics of the test, noting that the 'signe' will determine true from false resurrections:

Yf thowe be of so mycle might to make theym ete and drynke, for verey God we wyll the knowe such a sygne yf thow wyll shewe.

As Marsalek points out, in the cycle's play 'Emmaus' Jesus validates his own material resurrection by breaking bread because a 'ghooste hath neyther fleshe ne bonne' (186) and 'to eate hath no powere' (199)..${ }^{50}$ Antichrist initially agrees to this sign of proof, replying, 'Ye dede men, ryse thrughe my postye, / and ete and drynke, that men may see, / and preve me worthest in deyte' (559-61). Elijah then qualifies the terms:

Have here brede bothe two.

But I moste blesse hyt or I goo, that the fende, mankyndes foo, one hit have no powere.

As he consecrates the bread, the real presence of the host becomes the ultimate test of true and false resurrections.

This scene clarifies the orthodox-heterodox line. The consecration marks not only the play's shift from parodic to earnest Latin but also the revelation of real and specious resurrections. Elijah consecrates the sacrament, saying

Thys brede I blesse nowe with my honde

in Jhesus name, I understonde,

$\cdots$

In nomine Patris - that all hathe wroghte -

et Filii virginis - that dere us boughte - 
et Spyrytus Sancti — ys all my thoghte one God and parsons thre.

$(569-70,573-6)$

The host has a 'pryntte ... upon yt' (579), making it a powerful synthesis of textual and material signs, and the play implies that Elijah raises it, as is standard after consecration. ${ }^{51}$ The two dead men both exclaim that 'to loke on yt I am not light' $(578,581) .52$ The intense orthodoxy (and anti-Lollardy) of this scene overtly attempts to solidify audience sympathy. (Interestingly, this moment of consecration was also the target of reformer Christopher Goodman's objections to the cycle's Catholic elements; he specifically disapproves of the 'Antichrist' play's 'Elias blessing bread with the sign of the Cross. ${ }^{53}$ )

The host then becomes the third resurrection for Enoch and Elijah's side ${ }^{54}$ and proves to be the litmus test for true resurrection, as neither of the dead men can partake. The first cries, 'Alas, put that oute of my syghte! / To loke on yt I am not light' (577-8), while the second exclaims, 'That brede to me yt ys so bryght' (582). Both men echo that the bread 'puttyth me to grett fere' and 'grete dere' $(580,584)$. The kings also demonstrate that they have been 'converte[d] to hym' (587) when they each in turn renounce Antichrist as a heretic $(590,599)$ and vow to live 'for Jhesu sake' (611). The conspicuous raising of the host thus wins over the formerly dead men, the kings, and presumably the audience, to righteousness.

Near the end of the play, Antichrist attempts a recovery, and the stakes move from temporal to eternal resurrection. Antichrist kills Enoch and Elijah only to then be killed himself by the archangel Michael. Their three bodies become the next test sites for discerning true and false resurrections. Antichrist's specious claim to divinity is exposed first, as with 'bodye and sowle bothe in fere / and all gose to the devyll' (651-2). The stage directions indicate, 'Tunc morietur Antechristus et veniant duo demones' (652 sd), ${ }^{55}$ and it is possible, perhaps likely, that the two demons who drag him off to hell are played by the same actors who portrayed the two dead men falsely resurrected earlier. ${ }^{56}$ Such a casting choice would only reiterate the conclusion that Antichrist's pseudo-resurrections were indeed false.

In direct contrast, Enoch and Elijah confirm their theological positions with their own true resurrections, as the stage directions remark, 'sugent Ennoke e Helyas' (702 sd). ${ }^{57}$ They officially move from nondead to undead, a taxonomical shift they themselves confirm: Enoch says, 'I was dede and right here slayne, I but thrughe thy myght, lord, and thy mayne, / thowe hasse me raysyd up agayne' (707-9). Elijah refers to a bodily change, 'my fleshe nowe gloryfyed I see' (712), and (a little unsettlingly) echoes the exact words of the Primus Mortuus, 'for dede 
I wos and nowe lyve I. / Honoryd be thowe aye' (717-8). The archangel Michael, though, confirms these eternal resurrections to be true, first saying, 'My lorde wyll that ye with me gon / to hevens blysse, botthe blude and bon, / evermo there to be' (720-2) and then reiterating, 'to heven, there hymselffe ys, / nowe shall ye goe withe me' (725-6). His reference to 'blude and bon' also calls to mind the only other truly resurrected body to have been staged - that of Christ in the host.

The play's contest constructs a hermeneutic for discerning properly resurrected bodies based not simply on the 'verey signes' themselves but on specific, contextual qualities. First, resurrected bodies must be undead, not simply nondead, as the two dead men initially claim to be and as Enoch and Elijah eventually are. If the two dead men from the play's beginning double as the two demons at the play's end, their final identification as demons confirms their nondead status, and crucially, Antichrist's post-death body is never staged, as he is carried off to hell. Death necessarily precedes true resurrection, so much so that the play kills off the eternally-living Enoch and Elijah in order to properly resurrect them. Likewise, coding resurrection as a state of being undead, not simply nondead, affirms the bodily death of Christ, for if Christ was certainly resurrected, then he must have died first.

Secondly, resurrected bodies must consist of 'blude and bon' (720) and thus be able to 'ete and drynke' (548), a task Antichrist's dead men never complete. Christ's resurrected appearances tend to emphasize his materiality, such as his eating with his disciples on the road to Emmaus and on the shore of the Sea of Galilee, moments Luke later emphasizes when he asserts that the resurrected Christ appeared '[n]ot to all the people, but to witnesses preordained by God, even to us, who did eat and drink with him after he arose again from the dead' ${ }^{58}$ Most notably, his material body plays a central role in the doubting Thomas episode, a favorite in medieval English drama, and the Apostles' Creed also confirms 'the resurrection of the body' as a central orthodox tenet. Affirming true resurrection's bodily presence also has clear Eucharistic connections. While Lollards claimed that the host contained 'Christis body in the figure and not the veray body', the orthodox church insisted that real presence is material body and blood.59 Transubstantiation is not possible without a material substance into which to transition.

The Eucharistic nature of the play's resurrection theology harkens to its linguistic hermeneutical emphasis on contextual readings as crucial for discerning truth. Interpreting the verbal and material signs that the Chester 'Antichrist' presents hinges on orthodox practice and theology. Onstage, orthodox practice and 
theology collapse into the powerful synecdoche of the host. The play's deep reverence for and concern over stabilizing the significations of the Eucharist reflect the religious climate of its earliest performances, largely connected to the presence of Lollardy. Antichrist's parodic inversions of orthodox language and material presence challenge orthodox notions of absolute or univocal meaning and instead demand complex interpretive acts from the play's audience. Crucially, the Chester 'Antichrist' provides less a 'signe nowe men maye see' than signs that we must interpret.

\section{Notes}

My deepest thanks to Nicole Guenther Discenza, Sara Munson Deats, and David Bevington, who read drafts of this argument as a chapter of my dissertation 'Bite on Boldly': Staging Medieval and Early Modern Heretics; to Andrew Albin, who generously and astutely commented on multiple drafts of this article; and to Matthew Sergi, who provided much encouragement and support. Their feedback has been invaluable. All remaining errors are my own.

1 Sarah Beckwith, 'Ritual, Church and Theatre: Medieval Dramas of the Sacramental Body', David Aers (ed.), Culture and History 1350-1600: Essays on English Communities, Identities, and Writing (Detroit, 1992), 73.

2 Some of its scenes vary widely from the Group, others are absent entirely, and it conflates two Passion plays into a single one. See R.M. Lumianksy and David Mills (eds), The Chester Mystery Cycle (London, 1974), 1.xxviii.

3 Lumiansky and Mills, The Chester Mystery Cycle, 1.xi.

4 R.M. Lumianksy and David Mills (eds), The Chester Mystery Cycle: Essays and Documents (Chapel Hill, 1983).

5 Ibid, 86.

6 The Chester cycle also demonstrates a concern for unstable signs in 'The Purification of the Virgin', where a doubting Simeon attempts to change the prophecy in Isaiah by replacing the word 'virgin' with 'a good woman', but an angel twice changes the word back, thus affirming the inerrancy and stability of scripture.

7 David Mills (ed.), The Chester Mystery Cycle: A New Edition with Modernised Spelling (East Lansing, 1992), xii. Mills notes that evidence from the sixteenth century demonstrates that, at some point, the plays' performances moved to Whitsun week (xiv).

8 Ibid, xiii. 
9 Lumiansky and Mills (eds), Essays and Documents, 175. The six extant versions of the play demonstrate, as Richard Emmerson notes, that 'the play's text was basically fixed, at least through the time when the Exemplar was copied'. As adamant reformer Christopher Goodman's objections to the 1572 performance indicate, even the Reformation production preserved earlier, Catholic elements. See Richard Emmerson, 'Contextualizing Performance: The Reception of the Chester Antichrist', Journal of Medieval and Early Modern Studies 29.1 (1999), 97 and Elizabeth Baldwin, Lawrence M. Clopper, and David Mills (eds), REED: Cheshire Including Chester (Toronto, 2007), 148.

10 All quotations taken from 'Peniarth "Antichrist", Lumiansky and Mills (eds), The Chester Mystery Cycle.

11 Karen Sawyer Marsalek, 'Marvels and Counterfeits: False Resurrections in the Chester Antichrist and Henry IV, Part 1', Curtis Perry and John Watkins (eds), Shakespeare and the Middle Ages (Oxford, 2009), 230.

12 Emmerson, 'Contextualizing Performance', 97.

13 Ibid, 100. Emmerson raises the possibility of a Lollard audience member interpreting Antichrist as the pope in his section on the early Tudor period only to dismiss this possibility as remote due to Lollards' opposition to drama (100).

14 See John A.F. Thomson, The Later Lollards, 1414-1520 (London, 1965) and Christopher Haigh, Reformation and Resistance in Tudor Lancashire (Cambridge, 1975), as cited in Emmerson, 'Contextualizing Performance'. Anne Hudson, The Premature Reformation: Wycliffite Texts and Lollard History (New York, 1988), 126.

15 Hudson, The Premature Reformation, 127.

16 Lumiansky and Mills (eds), The Chester Mystery Cycle, 2.343n428.

17 Bernard McGinn, Antichrist: Two Thousand Years of the Human Fascination with Evil (San Francisco, 1994), 199.

18 Although Antichrist accuses Enoch and Elijah of being 'lowlers', the text's reverse coding of heresy suggests that the receiver of this accusation should be reversed as well, implying Antichrist, not Enoch and Elijah, is the Lollard. Antichrist's inability to partake of the host supports this reading.

19 I define univocity, or one-voicedness, as a model of language that does not admit an analogical or equivocal gap in meaning.

20 'Antichrist' contains a total of 722 lines, meaning that Antichrist remains verbally unnamed through roughly $90 \%$ of the play. There are, however, other hints of his heretical nature, such as calling Jesus' recent works 'wykydnes' done 'to forther falsed' $(29,27)$ and his scepticism of the Trinity, 'Wyll ye have bothe one God and iii? / Howe darr ye so say? / Maddmen' (499-501).

21 Emmerson, 'Contextualizing Performance', 99. 
22 Antichrist's conspicuous and fluid significations mean that he is not just a Lollard. In the case of the Chester 'Antichrist', his presence invokes a nexus of associations, the most dominant of which aligns Antichrist with Lollardy; however, both the Antichrist tradition and Lollardy itself were connected to Judaism and witchcraft. All three of these significations also develop Antichrist's central role in the play - to destabilize signs. See Cameron Hunt McNabb, 'Hocus Pocus and the Croxton Play of the Sacrament', Early Theatre 17.2 (2014), 16-17 for connections between Jews and Lollards and Marsalek, 'Marvels and Counterfeits', 223-4 for a discussion of Chester's Antichrist and magic.

23 See for instance Lawrence Clopper, 'Tyrants and Villains: Characterization in the Passion Sequences of the English Cycle Plays', Modern Language Quarterly 41.1 (1980), 3-20; Garrett P.J. Epp, 'Passion, Pomp and Parody: Alliteration in the York Plays', Medieval English Theatre 11 (1992), 150-61; and Jonathan Gil Harris, "'Look Not Big, nor Stamp, nor Stare": Acting Up in The Taming of the Shrew and the Coventry Herod Plays', Comparative Drama 34.4 (2000/2001), 365-98.

24 See for instance Warren Edminster, Preaching Fox: Festive Subversion in the Plays of the Wakefield Master (New York, 2005); Ruth Nisse, Defining Acts: Drama and the Politics of Interpretation in Late Medieval England (Notre Dame, 2005); and Lauren Lepow, Enacting the Sacrament: Counter-Lollardy in the Towneley Cycle (Rutherford, 1990). Edminster briefly connects some moments of subversion to Lollardy, but these are primarily thematic and ideological. He only addresses parody tangentially, when relevant to his reading of carnival and festive elements within the Towneley plays. Nisse examines similar traits in the York cycle, positing that it ' $\mathrm{draw}[\mathrm{s}]$ on heterodox ideas about translation, interpretation, and secular authority over Scripture' from Lollardy (24). Her study, however, assumes Lollard sympathy and also ignores parody. Only Lepow closely analyzes the heretical religious context of the plays, but her analysis focuses entirely on the Towneley Cycle.

25 Richard Emmerson, "Nowe Ys Common this Daye”: Enoch and Elias, Antichrist, and the Structure of the Chester Cycle', David Bevington (ed.), Homo Memento Finis: The Iconography of Just Judgment in Medieval Art and Drama (Kalamazoo, 1985), 90.

26 Tyndale uses this image to criticize the faulty logic of keeping the scriptures in Latin: 'If I must first believe the doctor, then is the doctor first true, and the truth of the scripture dependeth of his truth; and so the truth of God springeth of the truth of man. Thus antichrist turneth the roots of the trees upward'. Quoted in Janette Dillon, Language and Stage in Medieval and Renaissance England (New York, 1998), 75.

27 See Mt 4:1-11. 
28 Even more fundamental than Lollards' competing interpretations of scripture were their accusations of textual errors in the Vulgate. As the general prologue of the Wycliffite bible notes, readers 'no doute ... shal fynde ful manye biblis in Latyn ful false, if he loke manie, nameli newe'. Quoted in Hudson, The Premature Reformation, 244.

29 A linear audience experience is not assumed as members would enter and exit the cycle's performances for a variety of reasons and, with new actors playing each character in each play, few or no visual cues were initially present for who was Christ or who was Antichrist. A fragmented experience of the plays may thus have further complicated interpretation.

30 Richard Emmerson, “Englysch Laten' and 'Franch': Language as a Sign of Evil in Medieval English Drama', Alberto Ferreiro (ed.), The Devil, Heresy, and Witchcraft in the Middle Ages: Essays in Honor of Jeffrey B. Russell (Boston, 1998), 326.

31 Martin William Walsh notes this proportion in 'Demon or Deluded Messiah? The Characterization of Antichrist in the Chester Cycle', Medieval English Theatre 7.1 (1985), 17.

32 'From the high throne of the heavens, shining brighter than the sun, I have come down to make you see, to judge you. Living kings and rulers are put down beneath me. Be wise, believing in me always, and I shall make those who weep and grieve rejoice. Thus all nations placing hope in me shall rejoice. I have come down in your sight as a benevolent king and for your scrutiny; I am called "Eternal Prince, Christ, your Savior"'. Translation from Mills (ed.), The Chester Mystery Cycle, 390.

33 See for instance Jesus's Latin quotations in 'The Blind Man and Lazarus' (35 sd, $356 \mathrm{sd}$ ) and the 'Harrowing of Hell' (152 sd), and all of the prophets' in 'Antichrist's Prophets'.

34 See Mt 5:17.

35 'Of me it is said in the thirty-sixth chapter of Ezechiel: "For I will take you from among the heathen and gather you out of all countries, and will bring you into your own land". Translation from Mills (ed.), The Chester Mystery Cycle, 390. See Ez 36:24.

36 'About me it is said in a psalm: "In thy fear will I worship toward thy holy temple". Translation from Mills (ed.), The Chester Mystery Cycle, 391. See Ps 5:8.

37 Ps 5:6-7 DRV.

38 Ps 5:9 DRV.

39 "'He shall cause them to rule over many, and shall divide the land for gain", the thirteenth chapter of Daniel'. Translation from Mills (ed.), The Chester Mystery Cycle, 392. See Dn 11:39.

40 "“Therefore wait ye upon me, saith the Lord, until the day that I rise up to the prey; for my determination is to gather the nations, that I may assemble the kingdoms", 
Zephaniah 3'. Translation from Mills (ed.), The Chester Mystery Cycle, 394. See Zep 3:8.

41 Dn 13:36-9 DRV.

42 Zep 3:8 DRV.

43 Mills (ed.), The Chester Mystery Cycle, n390 ll 17-18.

44 'A new heart also will I give you, and a new spirit will I put within you'. Translation from Mills (ed.), The Chester Mystery Cycle, 396. See Ez 36:26.

45 'Rejoice in the Lord, O ye righteous'. Translation from Mills (ed.), The Chester Mystery Cycle, 413. See Ps 32:1. Mills notes that 'of the possible liturgical sources, the Communion of the Mass of Two or More Martyrs has been strongly proposed', The Chester Mystery Cycle, 1.728 sd n413.

46 Quoted in Hudson, The Premature Reformation, 228.

47 Dillon, Language and Stage, 31.

48 'Then Antichrist shall raise his body up, rising from the dead'. Translation from Mills (ed.), The Chester Mystery Cycle, 395.

49 Jn 5:24 DRV.

50 Marsalek, 'Marvels and Counterfeits', 220.

51 The visual scene of the consecration reinforces its orthodoxy as Enoch and Elijah are likely dressed as priests. During one of Antichrist's insults to Enoch and Elijah, he berates their attire, remarking, 'Eyche man may see you be so / all by your araye, / muffled in mantelles. Non such I knowe' (388-90).

52 For the consecration liturgy, see the Sarum Missal, http://justus.anglican.org/ resources/bcp/Sarum/index.htm.

53 Baldwin, Clopper, and Mills (eds), REED: Cheshire Including Chester, 148.

54 Medieval theology often connected the Eucharist is with the resurrected body of Christ. For example, Aquinas notes that Christ's bodily presence in the sacrament must be his resurrected body because 'His soul was truly separated from His body ... And therefore had this sacrament been celebrated during those three days when $\mathrm{He}$ was dead, the soul of Christ would not have been there, neither by the power of the sacrament, nor from real concomitance. But since "Christ rising from the dead dieth now no more" (Rm. 6:9), His soul is always really united with His body. And therefore in this sacrament the body indeed of Christ is present by the power of the sacrament, but His soul from real concomitance'. See Thomas Aquinas, Fathers of the English Dominican Province (trans.), The Summa Theologica, (New York, 1947), 3.Q76.

55 'Then Antichrist shall die, and two devils shall come'. Translation from Mills (ed.), The Chester Mystery Cycle, 410. 
56 Vassar College's production of the Chester 'Antichrist' in Toronto in 2010 utilized this casting possibility and identified these two characters as 'zombie/devil[s]'.

57 '[R]ising up, Enoch and Elijah'. My translation.

58 Acts 10:41 DRV.

59 Hudson, The Premature Reformation, 462. 